\title{
Morphometric Study of the Humerus Segments in Indian Population
}

\author{
Estudio Morfométrico de los Segmentos del Húmero en Población India
}

Somesh M. S.; Latha V. Prabhu; Shilpa K.; Mangala M. Pai; Ashwin Krishnamurthy \& B. V. Murlimanju

SOMESH, M. S.; PRABHU, L. V.; SHILPA, K.; PAI, M. M.; KRISHNAMURTHY, A. \& MURLIMANJU, B. V. Morphometric study of the humerus segments in Indian population. Int. J. Morphol., 29(4):1174-1180, 2011.

SUMMARY: The aim of the present study was to obtain the measurements of the different humerus segments and to estimate the length of humeri from them. For this purpose 100 (51 left and 49 right) sex-aggregated, adult dry humerus from Indian population, were taken to analyze the morphometric details of the humerus segments. The distance between five different segments viz: most proximal point of the humeral head and greater tuberosity (HA), head of the humerus and surgical neck of humerus (HB), proximal and distal point of olecranon fossa (HC), the distal point of olecranon fossa and trochlea of humerus (HD), proximal point of olecranon fossa and distal point of trochlea of humerus (HE) and finally the maximum length of humerus (HL) were obtained by means of an osteometrical board and an analogical caliper. Simples linear regressions $(\mathrm{p}<0.01)$ were made to correlate each segment with the total length of the humerus. Positive results were obtained in segments HB and HE of right humerus. Regressions formulae were obtained to define these estimative. In conclusion, our study demonstrated that length of the humerus can be estimated from measures of different segments of humerus and this study helps in forensic, anatomic and archeological cases in order to identify unknown bodies and to determine stature of the individual and as well as for the orthopedic surgeons for the treatment of proximal and distal humerus fractures and for their reconstruction.

KEY WORDS: Humerus segments; Morphometry; Forensic anthropology.

\section{INTRODUCTION}

Though much advancement in science has been done, but estimating the stature of the individual from bones and as well as reconstructions of life from the human skeletal still remains a challenge for many anthropologists and forensic experts. Statures estimated from the human skeletal remains is an important step in assessing health and general body size trends among the given populations (Hoppa \& Gruspier, 1996) and also have an important role in the identification of missing persons in to medico-legal investigations (Ross \& Konigsberg, 2002; Wright \& Vasquez, 2003).

In the absence of pelvis and cranium, morphometric analysis is frequently carried out on the remains of the long bones of the individual in anthropology and forensic science investigations (Nath \& Badkur, 2002; Beddoe, 1888; Petersen, 2005) and femur and tibia of the lower limb collectively remains the best for the assessment of living stature of the individual (De Mendonça, 2000; Radoinova et al., 2002). However in their absence, estimation of living stature can also be done from the long bones of the upper limb viz. Humerus, radius \& ulna (Celbis \& Agritmis, 2006; Kate \& Majumdar, 1976). For this purpose, either humerus can be used alone (Steele \& Mckern, 1969) or collectively with other bones of upper limbs (Mall et al., 2001), for the determination of sex and the estimation of stature of an individual.

Also, when thewhole of the long bones becomes unavailable in many situations, some methods have been employed for the usefulness of the fragments of long bones such as radius and femur (Mysorekar et al., 1980), femur and tibia (Steele \& Mckern), ulna and tibia (Mysorekar et al., 1984) and humerus (Wright \& Vasquez).

So, by knowing the measurements of different segments of the humerus, based on their articular surfaces and muscle attachments, total length of the humerus can be determined (Muñoz et al., 2001). 
Therefore, in the present study we made an attempt to determine the mean values of humerus segments in our population and compare with other populations and also to correlate measurements of some of the fragments of the humerus with its total length in the attempt of obtaining regression equations that allow us to estimate the humeral length from these fragments, which would assist in various medico legal and archaeological studies.

\section{MATERIAL AND METHOD}

Dry humerus bones of both the sides were obtained from the Bone bank of anatomy department, Kasturba Medical College, Manipal University Karnataka state, India. Morphometric measurements were done from 100 (49 right and 51 left) adult dry humerus. No determination of the sex was done. Bones in poor conditions or partly damaged were not considered. The lengths different segments of the humerus were determined using osteometric board with a precision of $0.1 \mathrm{~cm}$ (Salles et al., 2009), where in the humerus was kept on a clean graph sheet with well marked calibration with one end fixed (Fig. 1) and the measurements were again counter checked by using an electronic digital caliper (Akman et al., 2006). All measurements were obtained in millimeters $(\mathrm{mm})$. Six measurements were taken following the longitudinal axis of humerus shown in the Fig. 2 and Mean (M) and standard deviations (S.D) were calculated.

The association between the variables and length of humerus was investigated by means of Pearson's correlation coefficient ( $r$ ) and later linear regression was applied considering the right and left humeri separately. A probability (p) of less than 0.05 was considered statistically significant. All data analysis was done using SPSS software version11.5 for windows.

The measurement of five different segments of humerus was as follows:

A-B: Distance between the most proximal point on the articular segment of humeral head to the most proximal point of greater tuberosity (HA).

A-C: Distance between the most proximal point of head of humerus and surgical neck of humerus (HB).

D-E: Distance between most distal point and most proximal point along the edge of the olecranon fossa (HC).

E-F: Distance between the most distal point trochlea of humerus (HD). D-F: Distance between along the proximal edge of olecranon fossa and most proximal point of trochlea of humerus (HE).

And finally the maximum humerus length (HL) - the distance between the most proximal point on the head of humerus to most distal point of trochlea of humerus (A-F), is also obtained.

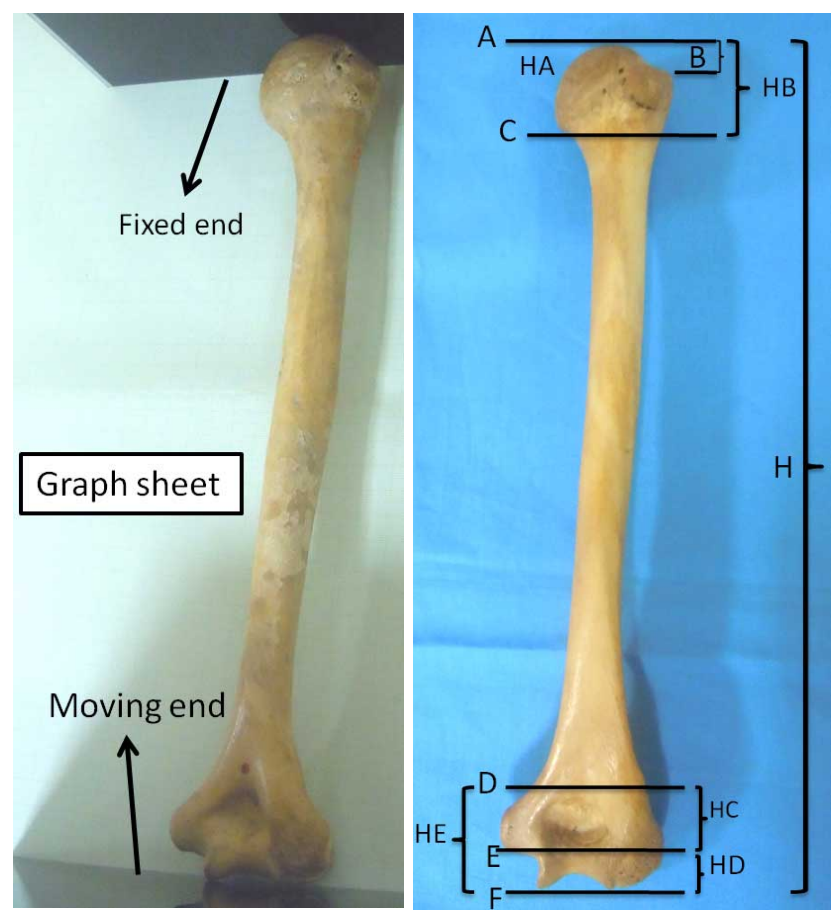

Fig. 1. Osteometrical board on which humerus is kept over the graph sheet with one end is fixed and other end moves.

Fig. 2. Measurements of segments of humerus; HL: Maximum length of the humerus; the distance between the most proximal point of the head of the humerus to the most distal point of the trochlea of the humerus (A-F), HA: The distance between the most proximal point of the articular segment of the humeral head and the most proximal point of greater tuberosity (A-B), HB: The distance between the most proximal point of the head of the humerus and surgical neck of the humerus (A-C), HC: The distance between the most distal point and most proximal point along the edge of olecranon fossa (D-E), HD: The distance between the most distal point of olecranon fossa and trochlea of humerus (E-F), HE: The distance between the proximal edge of the olecranon fossa and the most proximal point of trochlea of humerus (D-F).

\section{RESULTS}

Descriptive statistics. The mean values of different segments (HA, HB, HC, HD, HE) and as well as the maximum length of the humerus (HL) were determined as shown in the Table I, following the descriptions as shown in Fig. 2. No statistical test to analyze the differences between right and left sides was accomplished, because right and left humeri do not belong to same individuals.

Simple linear regression. Table II show the results of simple linear regression, involving different segments of 
humerus, respectively. Analyzing the results of simple regression, it was possible to observe that best estimative were obtained in the right side only and considering the right humerus, positive results were seen only in the segments $\mathrm{HB}$ and $\mathrm{HE}$, in decreasing order and are depicted in a scatter diagram (Figs. 3 and 4).

Simple regression formulae. Table III shows regression formulae for the estimative of humerus length from its different segments.

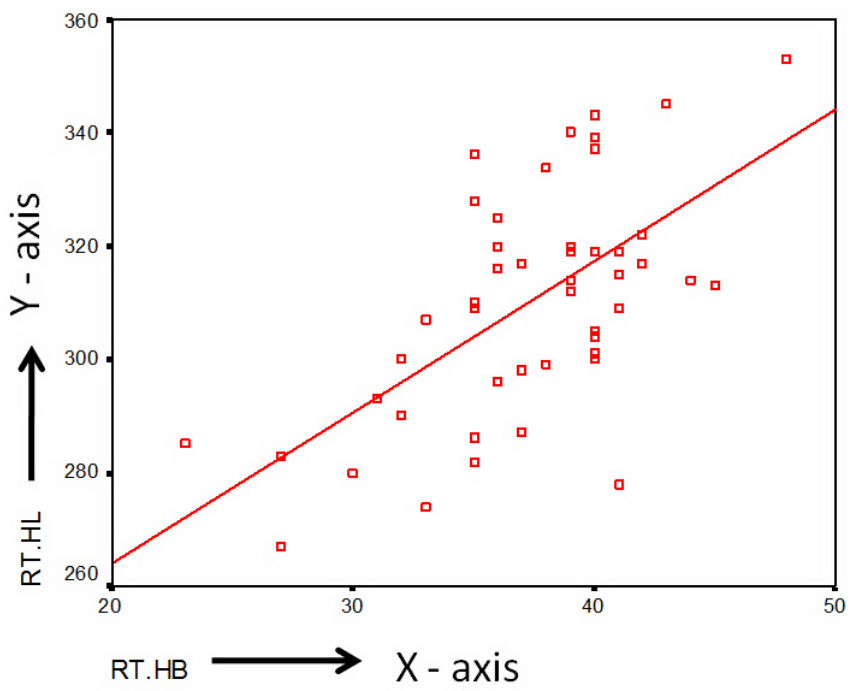

Fig. 3. Scatter diagram showing linear regression of right humerus with HB segment.
Table I. Table showing the Mean (M) and Standard deviation (SD) for segments of humerus (right and left humeri) in millimeter ( $\mathrm{mm}$ ). $\mathrm{HL}=$ Maximal Humeral Length (HA, HB, HC, HD, HE = different segment of humerus).

\begin{tabular}{|c|c|c|}
\hline $\begin{array}{l}\text { Segments of } \\
\text { Humerus }\end{array}$ & $\begin{array}{l}\text { Left Humerus } \\
(\mathrm{mm})(\mathrm{M} \pm \mathrm{SD})\end{array}$ & $\begin{array}{c}\text { Right Humerus } \\
(\mathbf{m m})(\mathrm{M} \pm \text { S. D })\end{array}$ \\
\hline $\mathrm{HA}$ & $5.8 \pm 1.5$ & $5.9 \pm 1.1$ \\
\hline HB & $37.7 \pm 4.4$ & 37. $1 \pm 4.8$ \\
\hline $\mathrm{HC}$ & $19.0 \pm 2.9$ & $20.1 \pm 3.4$ \\
\hline HD & $16.8 \pm 2.2$ & $37.2 \pm 4.7$ \\
\hline $\mathrm{HE}$ & $35.7 \pm 4.3$ & $37.2 \pm 4.7$ \\
\hline HL & $299.6 \pm 22.5$ & $309.6 \pm 20.6$ \\
\hline
\end{tabular}

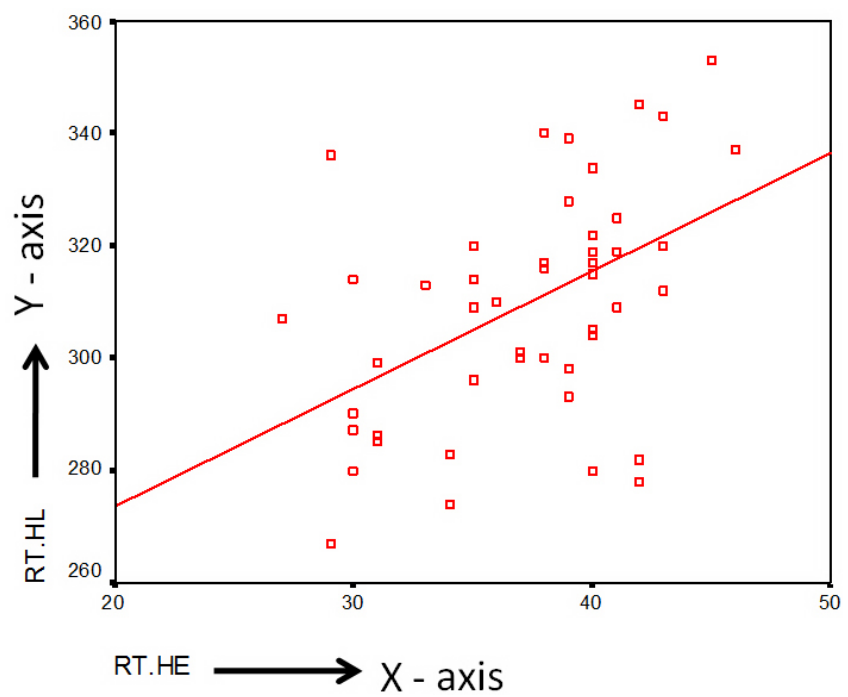

Fig. 4. Scatter diagram showing linear regression of right humerus with its segment HE.

Table II. Simple linear regression coefficients (Pearson), in the correlation between the humeral length and segments of humerus (right and left sides). Significant level p $<0.01$ (HA, HB, HC, $\mathrm{HD}, \mathrm{HE}=$ different segment of humerus).

\begin{tabular}{lccccc}
\hline \multirow{2}{*}{ Left Humerus } & HA & HB & HC & HD & HE \\
\cline { 2 - 6 } & 0.336 & 0.382 & 0.263 & 0.152 & 0.250 \\
Right Humerus & $(\mathrm{p}=0.016)$ & $(\mathrm{p}=0.006)$ & $(\mathrm{p}=0.062)$ & $(\mathrm{p}=0.288)$ & $(\mathrm{p}=0.077)$ \\
& 0.191 & 0.624 & 0.034 & 0.376 & 0.477 \\
& $(\mathrm{p}=0.188)$ & $(0.000)$ & $(0.817)$ & $(0.008)$ & $(0.001)$ \\
\hline
\end{tabular}

\begin{tabular}{ccc}
\hline $\mathbf{n}$ & Left Humerus & Right Humerus \\
\hline 1 & $\mathrm{HL}=271.46+4.83(\mathrm{HA})$ & $\mathrm{HL}=289.80+3.34(\mathrm{HA})$ \\
2 & $\mathrm{HL}=226.43+1.94(\mathrm{HB})$ & $\mathrm{HL}=210.46+2.67(\mathrm{HB})^{\#}$ \\
3 & $\mathrm{HL}=261.02+2.02(\mathrm{HC})$ & $\mathrm{HL}=305.57+0.20(\mathrm{HC})$ \\
4 & $\mathrm{HL}=273.61+1.30(\mathrm{HD})$ & $\mathrm{HL}=269.56+2.30(\mathrm{HD})$ \\
5 & $\mathrm{HL}=252.91+1.30(\mathrm{HE})$ & $\mathrm{HL}=22.00+2.02(\mathrm{HE})^{\#}$ \\
\hline
\end{tabular}

Table III. Table showing Simple regression formulae relative to the different segments of the humerus (right and left humeri) in millimeter $(\mathrm{mm})$. HL = Maximal Humeral Length (HA, HB, HC, $\mathrm{HD}, \mathrm{HE}=$ different segment of humerus). 


\section{DISCUSSION}

The humerus is the longest and largest bone of the upper limb and it is very important to identify its total length from their segmental measurements. In forensic anthropology, a method for estimating height based on the distances of segments of long bones becomes crucial and necessary.

Also, it has been shown that in forensic and archaeological studies, the mean value of total humerus length gives an important evidence to indicate the characteristic features of a population as a whole (Wright \& Vásquez; Mall et al.). So in our study, we obtained the mean values (Mean \pm S.D) of the maximum humerus length (HL) of the adult humerus in Indian population, on both sides. They were found to be $309.6+20.6 \& 299.6+22.5 \mathrm{~mm}$ on the right and left side respectively as against $307.1+20.6 \& 304 \pm 18.9$ in Turkish population (Akman et al.) and our values were comparable to both Turkish and Spanish population (Muñoz et al.). Also, there is a possible existence of differences within the Caucasian populations, since Bulgarians have greater whereas the Maya forensic samples have lower mean values than Turks (Willey \& Fasletti, 1991; Williams et al., 1989).

The distance from the most proximal point on the articular surface of the head of the humerus - to the distal point on surgical neck of humerus (HB) was $37.14 \pm 4.82 \mathrm{~mm}$ on the right $\& 37.74 \pm 4.45 \mathrm{~mm}$ on the left side respectively. When these values were compared against Turkish population it was $41.0 \pm 5.1 \mathrm{~mm}$ and $40.9 \pm 3.9 \mathrm{~mm}$ on the right and left side respectively (Akman et al.). Also, in a study from Guatemala with forensic Maya samples, the distance was $32.8 \pm 2.7 \mathrm{~mm}$ and it is therefore evident that there are differences in the values obtained as against previous studies (Zverev \& Chisi, 2005; Hertzog et al., 1969).

Previous studies reported that the highest point on the articular segment of the head of the humerus (HA) is about 6 to $8 \mathrm{~mm}$ above from the most proximal point on the greater tuberosity (Green \& Izzi, 2003; Iannotti et al., 1992) and this relationship is important because the relative height of the greater tuberosity determines the amount of subacromial clearance as the arm is elevated and for the treatment of isolated greater tuberosity fractures. In our study this distance was found to be $5.95 \pm 1.18 \mathrm{~mm} \& 5.83 \pm 1.57 \mathrm{~mm}$ on right and left side respectively, comparable to other anatomic studies (Akman et al.; Green \& Izzi; Iannotti et al.). So, the measurement of these proximal humeral segments becomes important in cases of proximal humeral fractures, which extends along the epiphysial lines of the proximal humerus and its segments, causing their displacement to various degrees.
Fractures of the distal segments of the humerus involving olecranon can occur as a result of hyperextension trauma to the elbow joint (Rommens et al., 2004). In an archaeological study, the distance between the proximal and distal edge of olecranon fossa (HC) was $20.2 \pm 1.9 \mathrm{~mm}$ for females and for males as $20.3 \pm 1.3 \mathrm{~mm}$ (Churchill \& Smith, 2000). The same distance in Turkish population was found to be $24.2 \pm 2.07 \mathrm{~mm}$ and $23.9 \pm 2.63 \mathrm{~mm}$ on the right and left humerus respectively (Akman et al.), as against 20.14 \pm 3.43 $\mathrm{mm} \& 19.06 \pm 2.92 \mathrm{~mm}$ observed in our study.

Moreover in another study, the distance between the distal margin of the olecranon fossa and trochlea (HD) on the right humerus was $14.2 \pm 1.8 \mathrm{~mm}$ for males (Wright \& Vásquez), whereas in the present study the same measurement was $17.37 \pm 3.36 \mathrm{~mm} \& 16.82 \pm 2.20 \mathrm{~mm}$ on right and left humerus respectively, less than that of Turkish population (Akman et al.).

The distal segment of the humerus articulates with the bones of the forearm and fractures involving it may pose several reconstructive problems and complications. Therefore these fractures gain special attention for orthopedic surgeons (Jupiter \& Mehne, 1992). Finally, when we assessed the distance from the proximal margin of the olecranon fossa to the distal trochlea (HE), it was found to be $37.26 \pm 4.71 \mathrm{~mm}$ on right humerus $\& 35.72 \pm 4.30 \mathrm{~mm}$ on left humerus and these values were much less as compared to the Turkish population (Akman et al.).

When we compare our present study with previous studies in the literature, the mean value of the total humerus length was similar to Spanish \& Turkish population, with some differences between Mayas and Bulgarians. The mean value of the distance from the humeral head to the greater tuberosity was comparable with other anatomic studies. However, differences are also found in the mean values of the distance from humeral head to surgical neck of humerus and from the distal margin of the olecranon fossa to the trochlea between Bulgarians and Turkish. Some differences are also found in the mean value of the olecranon fossa height compared with an archaeological study and our readings.

The reference points of the humerus were similar to the previous study (Akman et al.) and the authors however did not analyze possible differences among populations related to relationship between total humeral length and the measures of their segments. For this, regression analysis is a more appropriated method to define relationships between length of long bones and living height of individuals and as well as between the length of bones fragments and their maximum length (Nath \& Badkur; Krogman \& Is san, 1986) and many different studies have incorporated this statistical method 
for the estimation of stature from intact long bones of the upper and lower limbs for a very wide range of populations (Radoinova et al.; Trotter \& Gleser, 1952; Lund, 1983).

In the present study, we intended to estimate the humerus length from the measurements of the segments of humerus that will help in forensic or archaeological investigations. Results obtained on the right side were different from those observed on the left side, despite specimens were unmatched, that is, they did not belong to the same individuals. For this reason, direct comparisons between mean values of right and left sides were not accomplished. Positive results in the estimate of the humeral length, was shown with right side segments - HB and HE only. In a previous study, significant positive correlation with the humeral length was found in some fragments of both sides considering the proximal and distal ends and they could estimate the humeral length from these fragments and the results were obtained in right side (Salles et al.). However in our study only the longitudinal measurements and the associated proximal and distal segments of the humerus are considered.

As there is no information regarding the height of the individuals in the obtained anatomical collections of the present study, it was not possible to establish correlations between measurements of segments of the humerus and height of each person. Many studies have shown that the living height of the individual is an extremely variable parameter and could be influenced by a variety of confounding factors such as ethnicity, where stature may differ from one individual to another according to different populations (Steele \& Mckern; Galloway, 1988; Hertzog et al.; Willey \& Fasletti) and as a result, regression formulas obtained in an certain population should not be applied the other (Zverev \& Chisi).
Also, we cannot obtain any information about sex of individuals and thus, in our investigations data were sexaggregated and it is said that greatest accuracy in estimating living stature from long bones length will be obtained when sex and ethnic identity are available (Scheuer, 2002; Is san, 2005).

In conclusion, morphometric analysis suggests that there are some differences between the segments of humerus within different population groups. Also when compared to Turkish population alone, there was an overall decrease in the mean values of all the humeral segments in Indian population and in some segments, it is possible to estimate maximum length of the humerus with relative accuracy. This study creates perspectives not only to forensic investigations, because the estimate could be extended to living height of individuals, but also in archaeological material, considering similarities of the proportions about fragments of long bones.

We consider that these discrepancies could be attributed to various factors like ethnicity, age, sex, race, culture etc., along with environmental influence affecting bone growth such as nutrition, physical development and genetic factors. Moreover these diversities also relay on the differences in the reference points taken for the study. So these various factors should be kept in mind and further studies should be encouraged to determine the stature of an individual based on morphometry of different segments of humerus and to refer this to a population as a whole.

ACKNOWLEDGEMENTS. The authors are very thankful to Mr. M. S. Kotian, Department of community medicine, Kasturba Medical College, Mangalore, for his valuable help in the statistical analysis of the data.

SOMESH, M. S.; PRABHU, L. V.; SHILPA, K.; PAI, M. M.; KRISHNAMURTHY, A. \& MURLIMANJU, B. V. Estudio morfométrico de los segmentos del húmero en población India. Int. J. Morphol., 29(4):1174-1180, 2011.

RESUMEN: El objetivo del estudio fue obtener las medidas de diferentes segmentos del húmero y calcular la longitud del húmero a partir de ellos. Fueron seleccionados 100 (51 izquierdos y 49 derechos) húmeros adultos secos, separados por sexo, de población india para analizar los detalles morfométricos de los segmentos dle hueso. La distancia entre cinco segmentos diferentes fueron establecidos: punto más proximal de la cabeza humeral y la tuberosidad mayor (HA), cabeza del húmero y cuello quirúrgico del húmero (HB), punto proximal y distal de la fosa olecraneana (HC), punto distal de la fosa olecraneana y la tróclea del húmero (HD), punto proximal de la fosa olecraneana y punto distal de la tróclea del húmero (HE) y, finalmente, la longitud máxima del húmero (HL) medidas obtenidas por medio de una tabla osteométrica y un caliper análogo. Se realizaron regresiones lineales simples para correlacionar cada segmento con la longitud total del húmero. Se obtuvieron resultados positivos en los segmentos de HB y HE de húmero derecho. Fórmulas de regresión se obtuvieron para definir estimativos. En conclusión, nuestro estudio demostró que la longitud del húmero puede estimarse a partir de las medidas de los diferentes segmentos del hueso, ayudando en casos forenses, anatómicos y arqueológicos con el fin de identificar cuerpos desconocidos o para determinar la estatura de la persona, así como a cirujanos ortopédicos para el tratamiento de las fracturas proximales y distales del húmero o para su reconstrucción.

PALABRAS CLAVE: Segmentos de húmero; Morfometría; Antropología forense. 


\section{REFERENCES}

Akman, Ss. D.; Karakas, P. \& Bozkir, M. G. The morphometric measurements of humerus segments. Turk. J. Med. Sci., 36(2):81-5, 2006.

Beddoe, J. On the stature of the older races of England, as estimated from the long bones. J. Anthropol. Inst. Great Brit. Ireland, 17:202-7, 1888 .

Celbis, O. \& Agritmis, H. Estimation of stature and determination of sex from radial and ulnar bone lengths in a Turkish corpse sample. Forensic Sci. Int., 158(2-3):135-9, 2006.

Churchill, S. E. \& Smith, F. H. A modern human humerus from the early Aurignacian of Vogelherdh.le (Stetten, Germany). Am. J. Phys. Anthropol., 112(2):251-73, 2000.

De Mendonça, M. C. Estimation of height from the length of long bones in a Portuguese adult population. Am. J. Phys. Anthropol., 112(1):39-48, 2000.

Galloway, M. A. Estimating actual height in the older individual. J. Forensic Sci., 33(1):126-36, 1988.

Green, A. \& Izzi, J. Jr. Isolated fractures of the greater tuberosity of the proximal humerus. J. Shoulder Elbow Surg., 12(6):6419, 2003.

Hertzog, K. P.; Garn, S. M. \& Hempy, H. O. 3rd. Partitioning of the effects of secular trend and aging on adult stature. Am. J. Phys. Anthropol., 31(1):111-5, 1969.

Hoppa, R. D. \& Gruspier, K. L. Estimating diaphyseal length from fragmentary subadult skeletal remains: implications for palaeodemographic reconstructions of a southern Ontario ossuary. Am. J. Phys. Anthropol., 100(3):341-54, 1996.

Iannotti, J. P.; Gabriel, J. P.; Schneck, S. L.; Evans, B. G. \& Misra, S. Hundred and forty shoulders. J. Bone Joint Surg. Am., 74(4):491-500, 1992.

Is s can, M. Y. Forensic anthropology of sex and body size. Forensic Sci. Int., 147(2-3):107-12, 2005.

Jupiter, J. B. \& Mehne, D. K. Fracture of distal humerus. Orthopedics, 15(7):825-33, 1992.

Kate, B. R. \& Majumdar, R. D. Stature estimation from femur and humerus by regression and autometry. Acta Anat., 94:311-20, 1976.

Krogman, W. M. \& Is s can, M. Y. The Human Skeleton in Forensic Medicine. Springfield, Charles C. Thomas, 1986.

Lund, J. K. Regression equations for estimating living stature from long limb bones in the South African Negro. S. Afr. J. Sci., 79:337-8, 1983.
Mall, G.; Hubig, M.; Büttner, A.; Kuznik, J.; Penning, R. \& Graw, M. Sex determination and estimation of stature from the long bones of the arm. Forensic Sci. Int., 117(1-2):23-30, 2001.

Muñoz, J. I.; Liñares-Iglesias, M.; Suárez-Peñaranda, J. M.; Mayo, M.; Miguéns, X.; Rodríguez-Calvo, M. S. \& Concheiro, L. Stature estimation from radiographically determined long bone length in a Spanish population sample. Forensic Sci Int., 46(2):363- 6, 2001.

Mysorekar, V. L.; Nandedkar, A. N. \& Sarma, T. C. Estimation of stature from parts of the ulna and tibia. Med. Sci. Law, 24(2):113-6,1984.

Mysorekar, V. L.; Verrma, P. K.; Mandedkar, A. N. \& Sarmat, T. C. Estimation of stature from parts of bones--lower end of femur and upper end of radius. Med. Sci. Law, 20(4):283-6, 1980.

Nath, S. \& Badkur, P. Reconstruction of stature from long bone lengths. Int. J. Osteoarchaeol., 1:109-14, 2002.

Petersen, H. C. On the accuracy of estimating living stature from skeletal length in the grave and by linear regression. Int. J. Osteoarchaeol., 15:106-14, 2005.

Radoinova, D.; Tenekedjiev, K. \& Yordanov, Y. Stature estimation from long bone lengths in Bulgarians. Homo, 52(3):221-32, 2002 .

Rommens, P. M.; Küchle, R.; Schneider, R. U. \& Reuter, M. Olecranon fractures in adults: factors influencing outcome injury. Injury, 35(11):1149-57, 2004.

Ross, A. H. \& Konigsberg, L. W. New formulae for estimating stature in the Balkans. J. Forensic Sci., 47(1):165-7, 2002.

Salles, A. D.; Carvalho, C. R. F.; Silva, D. M. \& Santana, L. A. Reconstruction of humeral length from measurements of its proximal and distal fragments. Braz. J. Morphol. Sci., 26(2):55-61, 2009.

Scheuer, L. Application of osteology to Forensic Medicine. Clin. Anat., 15(4):297-312, 2002.

Steele, D. G. \& Mckern, T. W. A method for assessment of maximum long bone length and living stature from fragmentary long bones. Am. J. Phys. Anthropol., 31(2):21527,1969

Trotter, M. \& Gleser, G. C. Estimation of stature from long bones of American Whites and Negroes. Am. J. Phys. Anthropol., 10(4):463-514, 1952.

Willey, P. \& Fasletti, T. Inaccuracy of height information on driver's licenses. J. Forensic Sci., 36(3):813-9, 1991. 
SOMESH, M. S.; PRABHU, L. V.; SHILPA, K.; PAI, M. M.; KRISHNAMURTHY, A. \& MURLIMANJU, B. V. Morphometric study of the humerus segments in Indian population. Int. J. Morphol., 29(4):1174-1180, 2011.

Williams, P. L.; Warwick, R.; Dyson, M. \& Bannister, L. H. The humerus. In: Gray's anatomy. $37^{\text {th }}$ Ed. Edinburgh, Churchill Livingstone, 1989. p.406

Wright, L. E. \& Vásquez, M. A. Estimating the length of incomplete long bones: Forensic standards from Guatemala. Am. J. Phys. Anthropol., 120(3):233-51, 2003.

Zverev, Y. \& Chisi, J. Estimating height from arm span measurement in Malawian children. Coll. Antropol., 29(2):46973,2005 .
Correspondence to:

Dr. Somesh M.S.

Assistant Professor, MD,

Department of Anatomy, Centre for Basic Sciences (CBS)

Kasturba Medical College, Bejai, Mangalore - 575004

Manipal University, Karnataka

INDIA

Phone: 91-0824-2211767

Cel.: 09686924032

Email: drsomeshms@gmail.com

Received:18-08-2010

Accepted:22-06-2011 